\title{
Teaching NeuroImages: Presentation of diffuse large B-cell lymphoma with bilateral sequential oculomotor neuropathy
}

Krishna M. Galla, MBBS, Erin Cameron-Smith, MD, Sara H. Bares, MD, Alexander Braun, MD, Michael Punsoni, MD, Kirk Foster, MD, Jason Helvey, MD, and Sachin Kedar, MD

Neurology ${ }^{\circledR}$ 2018;91:e92-e93. doi:10.1212/WNL.0000000000005735
Correspondence

Dr. Kedar

sachin.kedar@unmc.edu

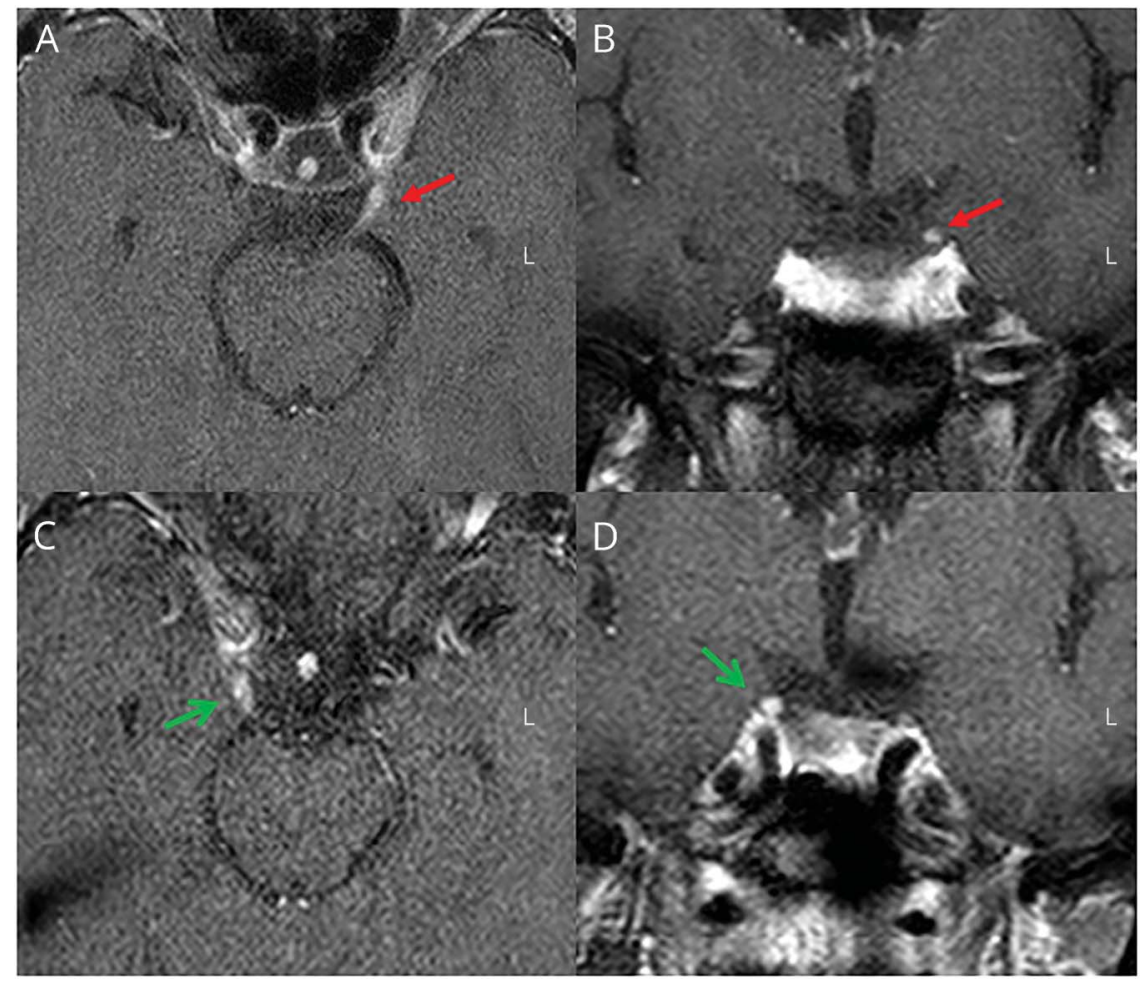

Axial (A, C) and coronal ( $B, D)$ sections show nonexpansile enhancement of left (red arrows) and right (green arrows) oculomotor nerve.
A 56-year-old man with HIV on combination antiretroviral therapy (CD4 count 368 cells/ $\mu \mathrm{L}$; HIV-RNA $<20$ copies $/ \mathrm{mL}$ ) had sequential, bilateral oculomotor nerve palsy after recent travel to Africa. Nonexpansile enhancement of the oculomotor nerves was noted on MRI (figure 1). Multiple CSF studies showed lymphocytic pleocytosis without neoplastic cells. Molecular testing on the serum was positive for Plasmodium falciparum by PCR early in the course of presentation but symptoms progressed despite treatment for $P$ falciparum. Infectious etiologies including Cryptococcus neoformans, histoplasmosis, varicella-zoster virus, herpes simplex virus, and JC virus were ruled out. He developed multiple cranial neuropathies (bilateral 3rd, 5th, 9th, and 10th) and encephalopathy and died of cytomegalovirus-related cardiopulmonary complications. Lymphadenopathy was not observed during the course of his illness. Autopsy
MORE ONLINE

\section{$\rightarrow$ Teaching slides}

links.lww.com/WNL/A544

From the Departments of Neurological Sciences (K.M.G., E.C.-S., S.K.), Infectious Disease (S.H.B.), Pathology (A.B., M.P., K.F.), and Radiology (J.H.), and Stanley M. Truhlsen Eye Institute (S.K.), University of Nebraska Medical Center, Omaha.

Go to Neurology.org/N for full disclosures. Funding information and disclosures deemed relevant by the authors, if any, are provided at the end of the article. 


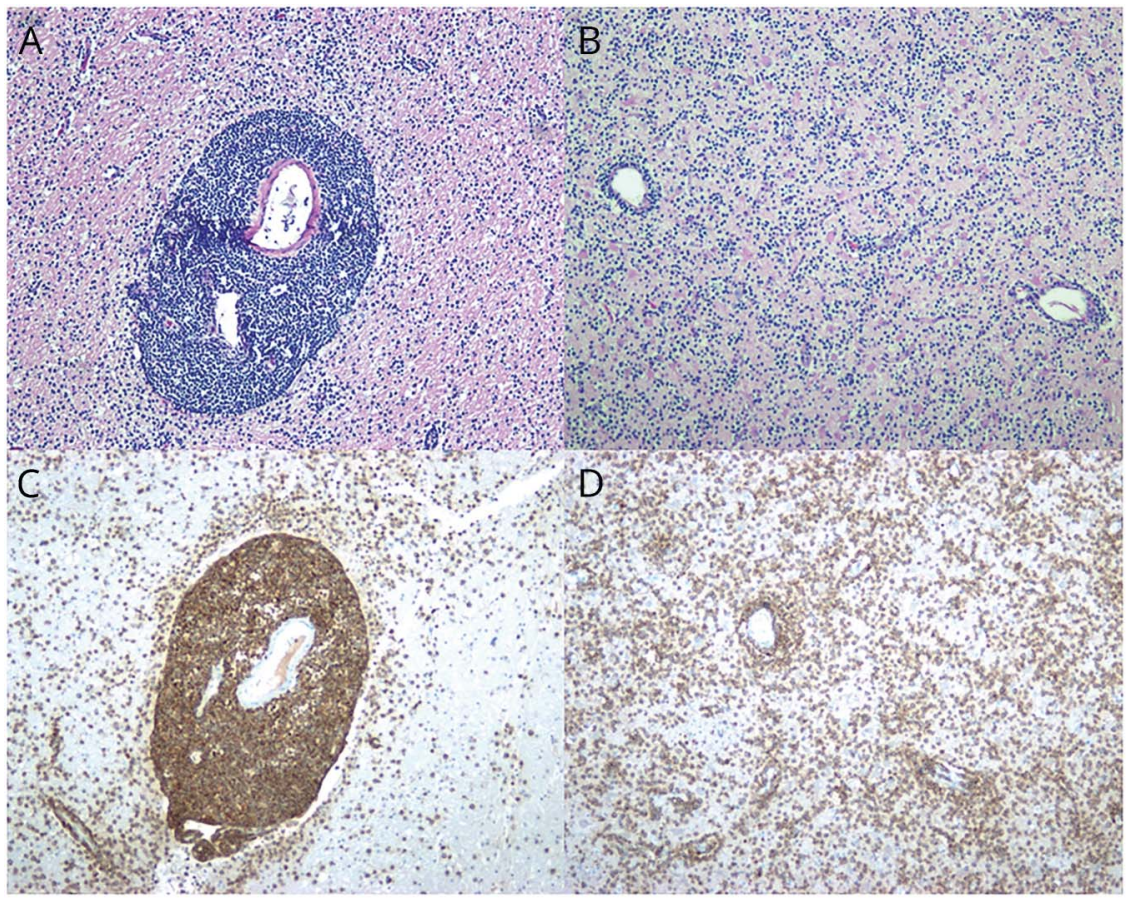

Hematoxylin \& eosin-stained sections show perivascular (A) and infiltrative (B) patterns of involvement by diffuse large B-cell lymphoma. Immunohistochemistry demonstrates expression of CD79a B-cell marker (C, D). Original magnification $\times 10$.

revealed intracranial and pericardial diffuse large B-cell lymphoma (DLBCL) (figure 2). Isolated oculomotor palsy is a rare presentation of DLBCL, with fewer than 20 reported cases. ${ }^{1,2}$ The risk for DLBCL, an AIDS-defining illness, increases with decreasing CD4 counts; however, it can occur in HIV despite normal CD4 counts. ${ }^{3}$

\section{Author contributions}

Krishna M. Galla: data acquisition, analysis of data, manuscript writing. Erin Cameron-Smith: data acquisition, analysis of data, editing. Sara H. Bares: editing for intellectual content. Alexander Braun: image contribution, interpretation of pathology slides. Michael Punsoni: image contribution, interpretation of pathology slides. Kirk Foster: image contribution, interpretation of pathology slides. Jason Helvey: image contribution, interpretation of radiology images. Sachin Kedar: critical revision of manuscript for intellectual content.

\section{Study funding}

No targeted funding reported.

\section{Disclosure}

K. Galla and E. Cameron-Smith report no disclosures relevant to the manuscript. S. Bares-received research funding from Gilead Sciences. A. Braun, M. Punsoni, K. Foster, and J. Helvey report no disclosures relevant to the manuscript. S. Kedar reports being a coinventor for the Advanced Pupil Simulator licensed by EON Reality Inc. Go to Neurology.org/ $\mathrm{N}$ for full disclosures.

\section{References}

1. Sato H, Hashimoto T, Yoneda S, Hirabayashi K, Oguchi K, Higuchi K. Lymphoma as a cause of isolated oculomotor nerve palsy. J Clin Neurosci 2011;18:1256-1258.

2. Lee WW. Lymphoma presenting as cranial nerve neuropathies in HIV-infected patients. AIDS Read 2008; 18:606-610, 621.

3. Biggar RJ, Chaturvedi AK, Goedert JJ, Engels EA; HIV/AIDS Cancer Match Study. AIDS-related cancer and severity of immunosuppression in persons with AIDS. J Natl Cancer Inst 2007;99:962-972. 


\section{Neurology}

\section{Teaching NeuroImages: Presentation of diffuse large B-cell lymphoma with bilateral sequential oculomotor neuropathy}

Krishna M. Galla, Erin Cameron-Smith, Sara H. Bares, et al.

Neurology 2018;91;e92-e93

DOI 10.1212/WNL.0000000000005735

\section{This information is current as of July 2, 2018}

\section{Updated Information \& Services}

References

Subspecialty Collections

Permissions \& Licensing

Reprints including high resolution figures, can be found at: http://n.neurology.org/content/91/1/e92.full

This article cites 3 articles, 0 of which you can access for free at: http://n.neurology.org/content/91/1/e92.full\#ref-list-1

This article, along with others on similar topics, appears in the following collection(s):

Diplopia (double vision)

http://n.neurology.org/cgi/collection/diplopia_double_vision HIV

http://n.neurology.org/cgi/collection/hiv

Metastatic tumor

http://n.neurology.org/cgi/collection/metastatic_tumor

Information about reproducing this article in parts (figures,tables) or in its entirety can be found online at:

http://www.neurology.org/about/about_the_journal\#permissions

Information about ordering reprints can be found online:

http://n.neurology.org/subscribers/advertise

Neurology ${ }^{\circledR}$ is the official journal of the American Academy of Neurology. Published continuously since 1951, it is now a weekly with 48 issues per year. Copyright @ 2018 American Academy of Neurology. All rights reserved. Print ISSN: 0028-3878. Online ISSN: 1526-632X.

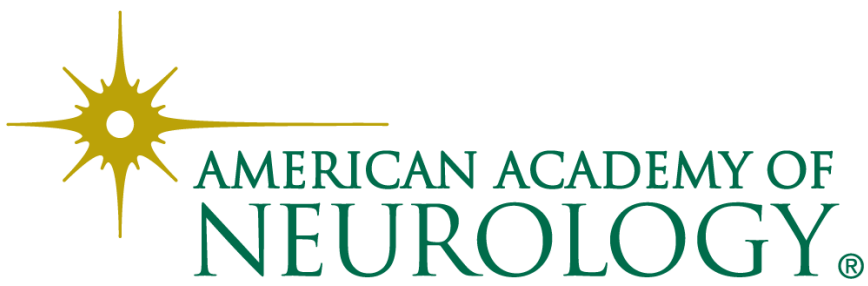

